\title{
Using Integrated Course Design for Flipped Classroom to Promote Active Learning of Lean Six Sigma for Supply Chains
}

\author{
Huay Ling Tay
}

\author{
Singapore University of Social Sciences, Singapore
}

\begin{abstract}
This paper showcases an educational experience for a course titled - "Lean Six Sigma for Supply Chains" taught at university level, where an integrated course design to engage students in a flipped classroom method is used. The course design incorporates a synergy between Fink's integrated course design model, experiential learning activities and formative assessments. The primary aim is to engage students in active learning of the course content. Therefore, all learning activities are designed according to the course learning goals, curricular and assessment requirements, prior knowledge of the students, and learning modes that are available to the students. These aspects allow educators to determine what is to be discussed in the classroom and how to facilitate active learning in-class and out-of-class. The course also leverages on the online learning space to develop both asynchronous and synchronous learning activities in order to engage student in their learning. To achieve the course learning goals, students are stimulated to participate in these learning activities and self-directed learning, in order to gain discipline specific knowledge and skills. This paper provides practical advice for course designers and programme leaders on how they can adopt an integrated course design approach in designing instructional activities for a flipped classroom setting to enhance student engagement and learning.
\end{abstract}

Keywords: Integrated Course Design, Flipped Classroom, Active Learning, Experiential Learning, Lean Six-Sigma 


\section{Introduction}

Education systems around the world are facing immense challenges in training students with the methods and techniques to effectively prepare them in meeting the needs of the employment market. The shift in the educational process, from a traditional emphasis placed on a teaching-centred model to a learning-centred model is the current ethos in many educational institutions. Hence, the role of the educator has expanded to include a mentor, a guide and a coach for the student in their learning journey (Camps, 2017; Kolb and Kolb, 2017; MacPhail et al., 2019).

To meet these multi-faceted demands, educators need to be equipped with knowledge on critical course aspects in order to develop the learning content and adopt appropriate instructional strategies that best meet the students' learning needs. In particular, educators need to acquire:

- subject-matter mastery, broad understanding on learning psychology and teaching pedagogies,

- skills in instructional planning and lesson organisation, adaptive communication, class management including management of group dynamics, students' expectations, and providing effective assessments feedback,

- adaptive and positive attitudes towards embracing differences in students learning approaches, self-reflection, self-criticism, and a keen interest in the scholarship of teaching and learning.

Under such a premise, this paper showcases a course that was designed for engaging students in active learning of the course content. The course is titled - "Lean Six Sigma for Supply Chains" (hereafter referred to as LSS), wherein Lean Six Sigma concepts and techniques are learned through applied learning opportunities in a six-week course schedule. To engage students in active learning throughout the course, a series of activities were thoughtfully crafted to allow students to participate in experiential learning (Kolb \& Kolb, 2017). A unique feature of the course is also to expose students to 'live' sites where theories and methodologies are being applied in practice in real-life business environment (Van Eynde and Spencer 1988). Several hands-on activities that allow students to participate in experiential learning across the six-week lesson plans were also crafted to facilitate students' active learning of the subject instead of the one-way traditional classroom lecturing model.

\section{Active Learning using Flipped Classroom Method}

According to Silberman (1996), active learning involves the engagement of students in dynamic and proactive learning activities where they do things and on their learning experience. Active learning requires students to participate actively in the learning process and is hardly possible through a traditional model of lecturing and reading texts (Camps, 2017; Michael, 2006; Silberman, 1996). Therefore, it is paramount to develop lesson plans that facilitate active learning with the inclusion of team-based learning, problem solving, experiential learning, and case discussions etc. A critical

International Journal of Management and Applied Research, 2021, Vol. 8, No. 1 
element in all these learning activities is that they provided avenues for interactions among instructors and students with the course contents in order to facilitate the active learning process.

For flipped classroom to be effective, there has to be an emphasis on self-directed learning where students have the responsibility of accomplishing preliminary activities before going back to school (Bates et al., 2017; Nerantzi, 2020). To facilitate students in their own learning construction, the lessons were designed to focus the time inside classroom for assimilating knowledge through active learning strategies like problem solving, 'live' industry case discussions and debates. Whilst outside of the classroom, students gain first exposure to the course content through learning resources such as chunked lecture recordings, videos, interactive study guide, online quizzes, as well as asynchronous online activities via the discussion boards on the Learning Management System (LMS).

\section{Nature of the Lean Six Sigma for Supply Chains Course}

This paper is based on a model used for the course development and instructional design of an elective course taught in an university's supply chain management program - Lean Six Sigma for Supply Chains. The course is a level three undergraduate course that is taken as an elective by students studying in the Business School. The course brings together the key aspects of Lean and Six Sigma management principles into a structured approach to improve supply chain performance (Antony, 2011). Students are expected to learn the key Lean Six Sigma principles and techniques that could aid organisations in balancing process flows, reducing process variation that ultimately can translate to increased value for the customers.

The key topics that were covered under the LSS course include:

- Essentials of Lean Six Sigma

- DMAIC Toolkit for Define, Measure, Analyse, Improve and Control Phases

- Financial Ratios and Supply Chain Strategies

- Innovations \& Lean Six Sigma Applications

- Managing Lean Six Sigma for Success

The course focuses on developing students' capability to work together in solving problems using a prescriptive approach, called Define, Measure, Analyse, Improve, Control (DMAIC), to identify and understand the cause and effect relationships of factors that drive the embedded issues in the problems (Harry, 1998).

The learning goals and course content are designed and developed for students' acquisition of content specific knowledge and skills as well as transferable skills to achieve higher order of learning (Labinowicz, 1980).

The course aims to train students with the abilities that allow them to perform effectively and independently. Therefore, students are expected to demonstrate critical thinking in analysing and critiquing issues, creative thinking in generating new ideas

International Journal of Management and Applied Research, 2021, Vol. 8, No. 1 
and perspectives, and practical thinking in making decisions to solve problems as shown in Table 1.

Table 1: Student's specific and transferable skills in the LSS course

Knowledge and Skills
Demonstrate the importance of Lean
Six Sigma for improving supply chain
performance
Use of DMAIC techniques to analyses
supply chain processes
Propose suitable Lean Six Sigma tools
and techniques for process
improvements
Apply financial metrics for Lean Six
Sigma projects
Appraise the Lean Six Sigma
innovations for improving supply chain
operations
Examine the conditions for successful
Lean Six Sigma deployment
Relate the strategies and techniques in
Lean Six Sigma to the work
environment
Develop interpersonal skills to work
effectively in a team
Transferable Skills

Self-learning and time management skills

Analytical and critical thinking skills

Practical and problem solving skills

Analytical skills

Critiquing skills

Practical and problem solving skills in holistic form Practical and problem solving skills in authentic environment

Team work and collaborative skills

Source: Author

\section{Essential Course Aspects of LSS}

1. Educational strategies of LSS Course

\section{a. Instructional approach:}

The course is designed to be learner-centric to promote active learning and students' participation for learning Lean Six Sigma and DMAIC techniques for improving supply chain processes.

\section{b. Instructional format:}

The course is conducted in a seminar format, using team-based assignments and problem-based learning approach.

\section{c. Supportive technologies and content management systems used:}

Students have access to an online content management system - the university's inhouse Learning Management System (LMS), interactive e-study guide and e-textbook, digital learning resources, lesson recording video clips, and other supportive learning technological tools and content management tools such as shared Google Drive, Google Sheets, Google Doc, as well as analytical software such as Microsoft Excel, and Microsoft Visio. 


\section{Assessments Components of LSS Course}

- Students are graded based on class participations and attendances.

- Students must submit a weekly reflective $\log$ on the discussion board of the LMS.

- Students must complete and pass all the individual assignments, team-based assignments and final examination.

- Students must attend at least $75 \%$ of contact hours held in physical classes or online virtual classes in order to be sufficiently graded at the end of the semester.

\section{Course Development}

Traditionally, most of the management courses are conducted in a seminar format that includes individual as well as collaborative work. In this paper, a revamped model is introduced where classes are conducted in flipped classroom format (Bates et al., 2017), with a mix of face-to-face, virtual contact hours and asynchronous online activities that are supported by digital learning resources. The average contact hours are three hours a week.

In view of the need to train students in practical skills, critical thinking and problem solving skills, thoughtful modifications of the instructional strategies and learning resources were developed to facilitate experiential learning of the course content (Kayes, 2002). Several of the activities incorporated problem-solving opportunities for the students to analyse and synthesize the theoretical learning from tacit resources to solve real world business problems. Table 2 shows the overall instructional design of the course, where flipped classroom method is used in the course delivery.

Table 2: Overall instructional design - a flipped classroom approach

\begin{tabular}{l} 
Out-of-Class \\
\hline Student's lesson preparation and self- \\
directed learning using Study Guide, \\
textbook, PowerPoint slides, online videos, \\
online quizzes
\end{tabular}

Applied learning using live case studies In-Class through company/site visits and industry talks led by industry practitioners and course instructor

Reflection using triggers such as "What lessons have I learnt? How can I put what I have learnt into practice (in my work, study, life)?"

Applied learning through instructor-led seminar, case studies, problem-solving exercises with PC, industry talks, small-group discussion and presentation, individual and group assignments that are industry-based

Source: Author

International Journal of Management and Applied Research, 2021, Vol. 8, No. 1 


\subsection{Integrated course design and instructional strategies}

We adopted the integrated course model (Fink, 2003) to guide in the sequential structuring of the LSS course content over the six-week lessons. The average class size for the course is thirty-five students.

Fink's integrated course design model identifies three key components of instructional design that are put together in an interrelated manner. The three interrelated components of instructional design are: (1) analysing the situational factors, (2) formulating the learning goals design, the feedback and assessment procedures, and (3) selecting the teaching and learning activities. The conceptual model is depicted in Figure 1.

Figure 1: Fink's Model of Integrated Course Design

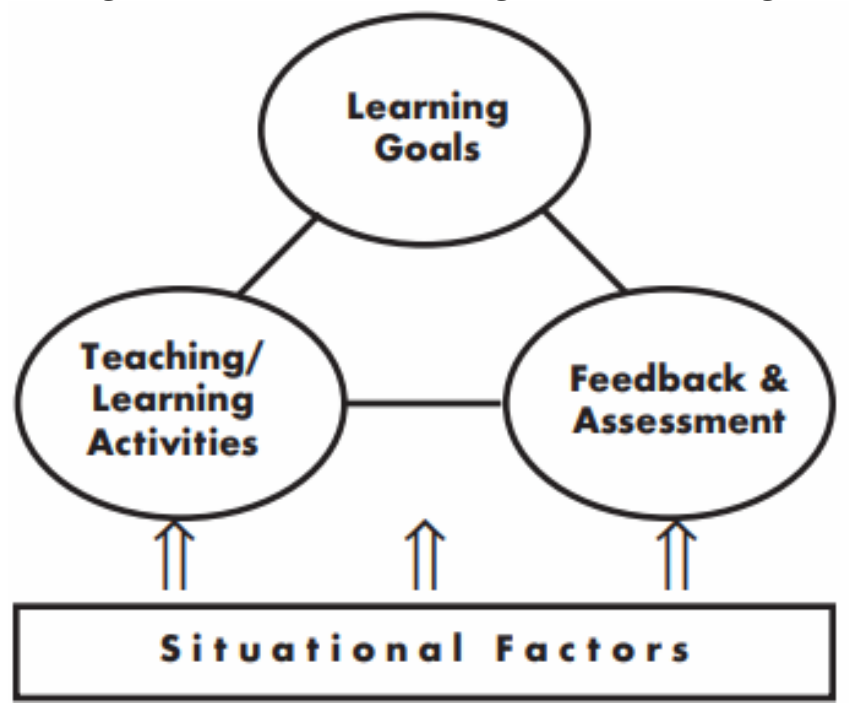

Source: Fink (2003)

The integrated course design model specifies that instructional design should carry out a number of steps in an interrelated manner that first identify important situational factors, based on the information acquired, make three important sets of decisions pertaining to (i) learning goals, (ii) feedback and assessment, and (iii) teaching/learning activities and finally making sure that these key components support and reinforce each other, thus ensuring integration.

In this course design, the sequencing of the course content was focused on providing opportunities for students to contextualize learning through experiential workshops, 'live' industry talks and interactions with practitioners, so that students can be convinced and relate theories to the real-world applications and challenges. Further, senior students who had applied the concepts successfully in their final year projects and work places were also invited to share their learning and experience so as to encourage the current students of the value and benefits of learning and applying the concepts in their future projects and work.

International Journal of Management and Applied Research, 2021, Vol. 8, No. 1 
Using Integrated Course Design for Flipped Classroom to Promote Active Learning of

Lean Six Sigma for Supply Chains

Table 3: Structured Sequence of LSS Course Content based on Fink's Model

\begin{tabular}{|c|c|c|c|c|c|c|}
\hline \multirow[b]{2}{*}{ Seminar } & \multicolumn{6}{|c|}{ Course Title: Lean Six Sigma for Supply Chains } \\
\hline & $\begin{array}{l}\text { Topic 1: } \\
\text { Essentials of } \\
\text { Lean Six } \\
\text { Sigma }\end{array}$ & $\begin{array}{l}\text { Topic 2: } \\
\text { DMAIC } \\
\text { Toolkit } \\
\text { for } \\
\text { Define, } \\
\text { Measure } \\
\text { and } \\
\text { Analyse } \\
\text { Phases }\end{array}$ & $\begin{array}{l}\text { Topic 3: } \\
\text { DMAIC } \\
\text { Toolkit for } \\
\text { Improve and } \\
\text { Control Phases }\end{array}$ & $\begin{array}{l}\text { Topic 4: } \\
\text { Lean Six } \\
\text { Sigma } \\
\text { Metrics } \\
\text { and } \\
\text { Supply } \\
\text { Chain } \\
\text { Strategies }\end{array}$ & $\begin{array}{l}\text { Topic 5: } \\
\text { Innovation } \\
\text { s and Lean } \\
\text { Six Sigma } \\
\text { Applications }\end{array}$ & $\begin{array}{l}\text { Topic 6: } \\
\text { Managing } \\
\text { Lean Six } \\
\text { Sigma for } \\
\text { Success }\end{array}$ \\
\hline $\begin{array}{l}\text { Learning } \\
\text { Goals }\end{array}$ & $\begin{array}{l}\text { Demonstrate } \\
\text { the } \\
\text { importance } \\
\text { of Lean Six } \\
\text { Sigma for } \\
\text { improving } \\
\text { supply chain } \\
\text { performance }\end{array}$ & $\begin{array}{l}\text { Use of } \\
\text { DMAIC } \\
\text { to analyse } \\
\text { supply } \\
\text { chain } \\
\text { processes }\end{array}$ & $\begin{array}{l}\text { Propose } \\
\text { suitable LSS } \\
\text { tools and } \\
\text { techniques for } \\
\text { process } \\
\text { improvements }\end{array}$ & $\begin{array}{l}\text { Apply } \\
\text { financial } \\
\text { metrics for } \\
\text { Lean Six } \\
\text { Sigma } \\
\text { projects }\end{array}$ & $\begin{array}{l}\text { Appraise } \\
\text { the Lean } \\
\text { Six Sigma } \\
\text { innovation } \\
\text { for } \\
\text { improving } \\
\text { supply } \\
\text { chain } \\
\text { operations }\end{array}$ & $\begin{array}{l}\text { Examine the } \\
\text { conditions } \\
\text { for } \\
\text { successful } \\
\text { Lean Six } \\
\text { Sigma } \\
\text { deployment }\end{array}$ \\
\hline Week 1 & $\begin{array}{l}\text { Ice-breaking } \\
\text { activities to } \\
\text { align } \\
\text { expectations } \\
\text { and } \\
\text { understand } \\
\text { hopes/fears. }\end{array}$ & & & & & \\
\hline Week 2 & \multicolumn{2}{|c|}{$\begin{array}{l}\text { Workshop at 'live' lean } \\
\text { simulation line, industry } \\
\text { talk and video. }\end{array}$} & & & & \\
\hline Week 3 & \multicolumn{3}{|c|}{$\begin{array}{l}\text { Industry talk and video to demonstrate the } \\
\text { end-to-end supply chain processes, linking } \\
\text { upstream supplies to demand nodes } \\
\text { dispersed across the island. The use of } \\
\text { innovation such as contactless delivery was } \\
\text { also explored. }\end{array}$} & & & \\
\hline Week 4 & \multicolumn{4}{|c|}{$\begin{array}{l}\text { Experience sharing by seniors who have successfully } \\
\text { applied the theories and techniques learned from the } \\
\text { course in their final year projects and work. }\end{array}$} & & \\
\hline Week 5 & \multicolumn{5}{|c|}{$\begin{array}{l}\text { A 'live' industry case analysis of a logistics company that has } \\
\text { leveraged on innovations and industry } 4.0 \text { solutions to attain Lean Six } \\
\text { Sigma performance in the supply chains. }\end{array}$} & \\
\hline Week 6 & \multicolumn{6}{|c|}{ Course review and preparation for final examination. } \\
\hline
\end{tabular}

Source: Author

In accordance to Fink's integrated course design model, the instructional activities are planned in such way that for each new topic that was discussed, students would be introduced to the topic, followed by opportunities to apply the concepts in activities and assessments. The students are assessed based on their class participations, individual assignments, group-based assignments as well as the final examination. The

International Journal of Management and Applied Research, 2021, Vol. 8, No. 1 
assignments and activities are also sequenced in order of increasing complexity. In another words, assignments and activities become more complex, which requires more interactions and synthesis of the topics that are learned over the weeks. Table 3 shows the structured sequence of the LSS course content based on Fink's Model of integrated course design.

The following activities are designed to enable active learning of the course content:

- Week 0 - Student's self-directed learning and seminar preparation using interactive study guide, digital learning resources including e-textbook, seminar PowerPoint slides, chunked lecture recordings, online videos, and online quizzes.

- Week 1 - Course introduction and overview of learning content, activities and formative assessments and grading.

- Week 2 - An on-site simulation workshop conducted at an institutional partner's lab, where the students were able to observe and role-play as operators at the respective workstations in a lean environment.

- Week 3 - Video and 'live' industry talk at an exemplary company that has implemented Lean Six Sigma a guiding principle for its business and process improvements

Industry Talk and video to demonstrate the end-to-end processes linking upstream supplies to demand spread across the island.

- Week 4 - A 'live' experience sharing by a senior who has applied Lean Six Sigma in the final year project as the problem solution framework.

- Week 5 - A 'live' industry case analysis on innovation and Lean Six Sigma for supply chains, applications of industry 4.0 technologies to drive process excellence, online quizzes and videos.

- Week 6 - Course review, revision and preparation for the final examination.

To promote active learning in the online learning space, a mix of asynchronous and synchronous activities and formative assessments are crafted for students to reflect on several key content and critical success factors that can guide an organisation to successfully implement Lean Six Sigma in different contexts. In order to provide students with opportunities to learn, do, act and apply the theoretical concepts and techniques of LSS, a 4 'A's of lesson planning approach was adopted in the instructional design for all the seminars in a sequential manner as depicted in Figure 2. The 4 'A's of lesson planning: - (1) Activate Prior Knowledge, (2) Acquire New Knowledge, (3) Application and (4) Assessment.

Figure 2: The 4 'A's of lesson planning

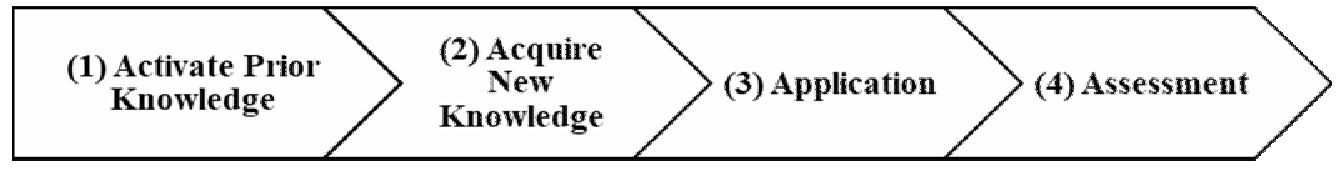

Source: Author

International Journal of Management and Applied Research, 2021, Vol. 8, No. 1 
Using Integrated Course Design for Flipped Classroom to Promote Active Learning of

Lean Six Sigma for Supply Chains

A sample of the 4 'A's of lesson planning template that is used for guiding the instructional design for the six-week course is depicted in Figure 3.

Figure 3: A sample of the 4 'A's of lesson planning template

\section{4 'A's of lesson planning}

Activate Prior Knowledge: Access prior knowledge/ activate students'schemas

Methods: $\square$ Gallery walk $\square$ Brainstorming $\square$ Concept mapping $\square$ Games $\square$ Q\&A

Acquire New Knowledge: Foster inquiry throughout lessons and among students

Methods: $\square$ Leaning logs $\square$ Industry speakers $\square$ Mini lessons $\square$ Active reading

$\square$ Q\&A $\square$ Viewing + listening $\square$ Note making $\square$ Group discussions $\square$ Journals

Application: Consolidate what has been learned and make it relevant

Methods: $\square$ Learning logs $\square$ Simulation $\square$ Case study $\square$ Debriefing

$\square$ Real world activities $\square$ Scenario Analysis $\square$ Role play $\square$ Think/pair/share

Assessment: Assess what has been learned and what needs to be further developed

Methods: $\square$ Quizzes $\square$ Open and closed book tests $\square$ Think/pair/share

$\square$ Small conferences

Source: Humber College (n.d.)

The following section describes an example where the 4 'A's of lesson planning was used to design the experiential workshop at the lean simulation line.

\section{(1) Activate Prior Knowledge}

At the start of the semester, to access prior knowledge and activate students' schemas of the subject concepts, students were engaged in brainstorming and concept mapping exercise to assist them in recalling their previous exposure to the learning materials as well as past experience in their work. Before the in-class session, students were required to complete the online quizzes. Students are provided with the course reading materials and access to the online learning content once they are enrolled in the course.

\section{(2) Acquire New Knowledge}

Students were encouraged to activate their previously acquired knowledge in order to critically evaluate possible scenarios and analyse possible solutions. When most of the students were not able to handle a specific problem, a team-based approach was followed whereby a discussion was typically initiated by the instructor to explore the potential problem solving strategies or alternative views. During the initial phase of the problem solving phase, more specific guidance was provided to students when many of students were unsure or unconfident about the direction to take.

International Journal of Management and Applied Research, 2021, Vol. 8, No. 1 
In addition, regular consultations either through face-to-face or virtual platforms were scheduled with the students to assess their learning progress and provide follow-up clarifications on specific ambiguities that were not addressed fully, especially for complex problems that were convoluted with diverse issues that might not be sufficiently addressed in a single lesson. These consultation sessions that were conducted on an individual and group basis also served as a channel for the instructor to connect to students in a more informal manner. Such connections helped to deepen trust and strengthen relationships between the instructor and students, which also supported students' interest in learning the subject. Establishing such channel helped the instructor to adapt learning activities according to the individual student's learning curve, prior academic background and experience. Other times, the students would work either independently or collaboratively within their peer groups.

The learning activities were conducted using a range of platforms, including the LMS discussion boards, asynchronous content sharing site (Padlet), shared Google Docs and Sheets. All these tools can be readily accessed via the Internet using web browsers such as the Google Chrome, Opera, Microsoft Edge or Firefox, thus providing the participants with a high level of flexibility and accessibility. All the digital course content resources - interactive e-study-guide, e-textbook and online assessments and quizzes are also accessible by students on their personal computers.

\section{(3) Application - through experiential learning, 'live' industry case analyses and discussions}

The aim was to promote higher order thinking, enable students to make connections and interconnections between the course material and real life experiences, as well as to stimulate inquiry and learning throughout lessons. To do so, hands-on simulation sessions and sharing from industry speakers were thoughtfully incorporated to activate students' prior knowledge of the subject and enable them to connect the theoretical concepts that were discussed in the earlier segments of the course to 'live' applications of the concepts to authentic issues in the business supply chains.

During the simulation lab, students were required to consolidate what they have learned in analysing different possible scenarios. For example, in the workshop conducted in the lean simulation line, students were provided with worksheets that included learning activities involving role-playing at the different workstations and time-keeping tasks to collate evidence on the performance of the assembly line which activated their observation skills and knowledge on job design and bottleneck identifications.

A debriefing session was provided at the end of the workshop. After which, all students were required to submit a weekly reflective log to consolidate the applied learning experience.

\section{(4) Assessment - through weekly learning logs and feedback on Google Forms}

After each session, the students were also required to submit their learning logs for the lesson that facilitate them to consolidate their learning experience and reflect on the learning culminated over the weeks.

International Journal of Management and Applied Research, 2021, Vol. 8, No. 1 
The list of sections included in the learning log:

- Knowledge: What do you learn in today's session?

- Reflection: Key learning points, why are they useful?

- Action: How will you put today's learning into practice (to your study or your life)?

- Change \& Challenge: Articulate the most important learning/idea which will make you do things differently in the future (e.g. serving the society and community).

A sample of a learning log template is depicted in Figure 4.

Figure 4: A sample of a learning log template

\section{Learning Log}

Academic Year

Course Code

Course Title

Student Name

Student ID No.

Date

Topic/Title

Knowledge: What do you learn in today's session?

Reflection: Key learning points, why are they useful?

Action: How will you put today's learning into practice (to your study or your life)?

International Journal of Management and Applied Research, 2021, Vol. 8, No. 1 
Change \& Challenge: Articulate the most important learning/idea which will make you do things differently in the future (e.g. serving the society).

The submitted learning logs and reflections provided useful feedback about the experiential learning experience at the lean simulation line. In general, students were able to relate to the key principles of Lean Six Sigma and appreciate the unique perspective of Lean Six Sigma that is dominantly customer-centric and value-focused. Over the weeks, students were able to distinguish salient features of DMAIC concepts and techniques through their discussions and assignment papers that were submitted. The course learning goals were demonstrated by the students as students' applications of the concepts in the activities and submitted assignment papers were evident.

Furthermore, students were able to appreciate a) the practical business challenges faced by the practitioners and b) common concerns and challenges faced in the application of Lean Six Sigma theories and c) applicable methodologies for process improvements in authentic environments.

Most students appreciated the opportunity to learn off-campus at the lean simulation line. The following are some extracts of the feedback from the experiential learning experience at the lean simulation line:

"The learning experience conducted at the Simulation Lean Line was both engaging and insightful. There are times when concepts thought in-class are confusing and I would not be able to understand how it applies to the real world, and such learning experiences are beneficial in allowing me to grasp the concept not just in terms of its theory but also practically. Overall, I thoroughly enjoyed the lesson there and hope that more of such learning experiences can be conducted on either this course or other courses in future." - Student A

"What is the theory without real-life examples? What is knowledge without application? It was definitely interesting, interactive and informative sharing from Head of Innovation from XXX Logistics during the class." _ Student B

"The industry talk was very enriching and make me fully understand the importance of leveraging on technologies in Lean Six Sigma applications in the Logistics and Supply Chain ecosystem.”_Student C

"The industry talks and live simulation of the lean application enhances my understanding of the real world application of Lean Six Sigma and its challenges. It also helps me to link the theoretical concepts with practical implications." _ Student D

International Journal of Management and Applied Research, 2021, Vol. 8, No. 1 
Over the six weeks of lessons, the students went through a recurrent learning process schema as shown in Figure 5, which aims to support students in acquiring a life-long habit of learning independently and actively.

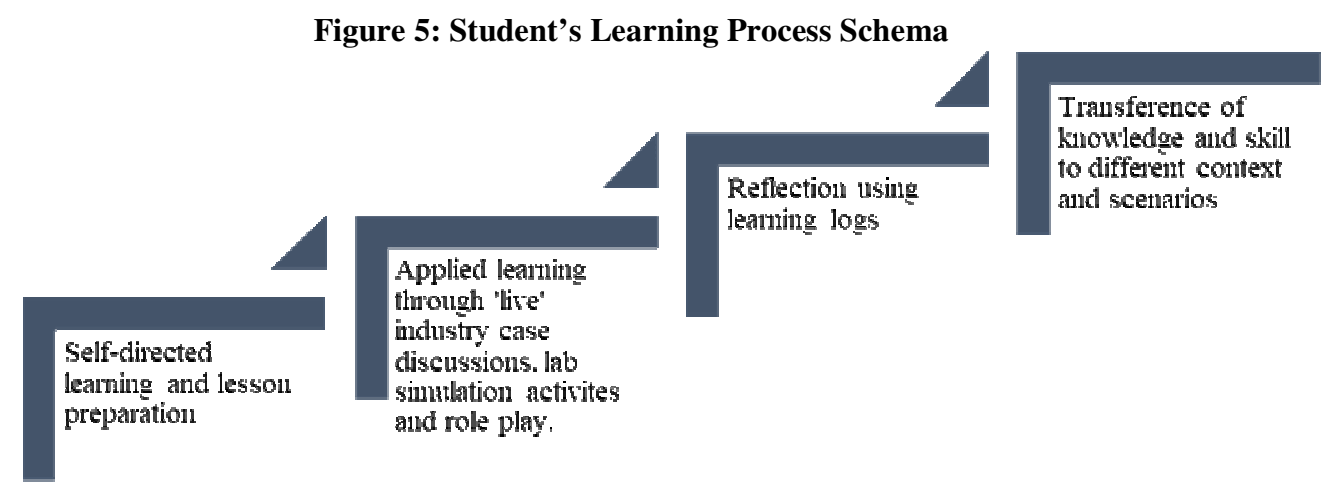

Source: Author

\section{Conclusion and Implications}

In this paper, we presented an integrated course design and instructional strategies for a six-week lesson plan that incorporated a mix of in-class and out-of-class activities to engage students in the learning process and application of theories through interactions with industry practitioners, who have practical experience in applying and implementing Lean and Six Sigma in their workplaces.

We diverted from the traditional classroom lecturing format to provide students with opportunities to learn, act and apply using a flipped classroom approach. The six-week course included thoughtfully crafted formative assessments and active learning activities, where the 4 'A's of lesson planning approach was adapted in the instructional design. The 4 'A's of lesson planning are: - (1) Activate Prior Knowledge, (2) Acquire New Knowledge, (3) Application and (4) Assessment. One such activity is the 'live' lean simulation line conducted at our partner's institution.

The off-campus activities, industry talks and site visits provided opportunities for students to engage in active learning, role playing and avenues for out-of-classroom interactions and authentic learning. Further, the insights shared by Lean Six Sigma practitioners and the senior students provided notable examples on how the course content can be practical and useful for real-life problem-solving and helped to promote students' interest and curiosity in learning the subject.

This paper contributes to the literature on active learning and teaching of Lean Six Sigma for management education. The use of 'live' cases for training problem-solving skills provided opportunities for students to interact and listen to the practitioners' point of view, beyond theoretical learning deriving from the textbooks and references. The learning activities also served to encourage students to apply Lean Six Sigma for solving issues encountered in their projects and work environment. In all, this paper serves as a reference to educator and training providers in facilitating active learning

International Journal of Management and Applied Research, 2021, Vol. 8, No. 1 
that connects theory with practice in various settings, and supports the facilitation of an applied learning journey, which would help to prepare students for the job market.

Finally, it is noteworthy that although it is important to have well thought-out lesson plans with adequate sequencing of learning activities to support learning using such technique as the 4 'As', the instructor's enthusiasm in encouraging active learning and willingness to adapt to learners' diverse ways of acquiring knowledge are vital driving forces to engender an effective learning environment.

\section{Declaration of Conflicting Interests}

The authors declared no potential conflicts of interest with respect to the research, authorship and/or publication of this article.

\section{References}

1. Antony, J. (2011), "Six Sigma vs Lean: Some perspectives from leading academics and practitioners", International Journal of Productivity and Performance

Management, Vol. 60, No. 2, pp. 185-190.

https://doi.org/10.1108/17410401111101494

2. Bonwell, C. and Eison, J. (1991), Active Learning: Creating excitement in the classroom: ASHE-ERIC Higher Education Reports. Washington, D.C.: George Washington University.

3. Bates J.E.; Almekdash H. and Gilchrest-Dunnam M.J. (2017), "The Flipped Classroom: A Brief, Brief History", in: Santos Green L. and Banas J., Perkins R. (eds), The Flipped College Classroom. Educational Communications and Technology: Issues and Innovations. Cham: Springer. https://doi.org/10.1007/9783-319-41855-1_1

4. Camps, N. (2017), "Analysing Challenges of Teaching Supply Chain Management in Higher Education Institutions", International Journal of Management and Applied Research, Vol. 4, No. 4, pp. 211-221. https://doi.org/10.18646/2056.44.17016

5. Fink, L. D. (2003), Creating Significant Learning Experience:, An Integrated Approach to Designing College Courses. San Francisco: Jossey-Bass.

6. Harry, M. J. (1998), "Six Sigma: a breakthrough strategy for profitability”, Quality Progress, Vol. 31, No.5, pp.60-64.

7. Humber College (n.d.), 4A lesson planning, [Online] available from: https://www.humber.ca/centreforteachingandlearning/assets/files/Teaching\%20Met hods/4A\%20of\%20Lesson\%20Planning.pdf [Accessed on 23 February 2021].

8. Kayes, D. C. (2002), "Experiential learning and its critics: Preserving the role of experience in management learning and education", Academy of Management

International Journal of Management and Applied Research, 2021, Vol. 8, No. 1 
Using Integrated Course Design for Flipped Classroom to Promote Active Learning of Lean Six Sigma for Supply Chains

Learning \& Education, Vol. 1, No. 2, pp. 137-149. https://doi.org/10.5465/AMLE.2002.8509336

9. Kolb, A. Y. and Kolb, D. A. (2017), "Experiential Learning Theory as a Guide for Experiential Educators in Higher Education”, Experiential Learning \& Teaching in Higher Education, Vol. 1, No. 1, Article 7, Available at: https://nsuworks.nova.edu/elthe/vol1/iss1/7

10. King, P. M. and Kitchener, K. S. (1994), Developing reflective judgment: Understanding and promoting intellectual growth and critical thinking in adolescents and adults, San Francisco: Jossey-Bass.

11. Kolb, D. (1984), Experiential learning, New Jersey: Prentice-Hall.

12. Labinowicz, E., (1980), The Piaget primer: Thinking, learning, teaching. California: Addison-Wesley.

13. MacPhail, A.; Ulvik, M.; Guberman, A.; Czerniawski, G.; Oolbekkink-Marchand, H. and Bain, Y. (2019), "The professional development of higher education-based teacher educators: needs and realities", Professional development in $\begin{array}{lllll}\text { education, Vol. } & 45, & \text { No. } & 5, & \text { pp. }\end{array}$ https://doi.org/10.1080/19415257.2018.1529610

14. Michael, J. (2006), "Where's the evidence that active learning works?", Advances in Physiology Education, Vol. 30, No. 4, pp. 159-167.

https://doi.org/10.1152/advan.00053.2006

15. Nerantzi, C. (2020), "The Use of Peer Instruction and Flipped Learning to Support Flexible Blended Learning During and After the COVID-19 Pandemic", International Journal of Management and Applied Research, Vol. 7, No. 2, pp. 184-195. https://doi.org/10.18646/2056.72.20-013

16. Silberman, M. (1996), Active Learning: 101 Strategies To Teach Any Subject, Des Moines: Prentice-Hall.

17. Thornton, G. C., III, and Cleveland, J. N. (1990), "Developing managerial talent through simulation", American Psychologist, Vol. 45, No. 2, pp. 190-199. https://doi.org/10.1037/0003-066X.45.2.190

18. Van Eynde, D. F. and Spencer, R.W. (1988), "Lecture versus experiential learning: Their differential effects on long-term memory", Organizational Behavior and Teaching Review, Vol. 12, No. 4, pp. 52-58. https://doi.org/10.1177\%2F105256298801200404

International Journal of Management and Applied Research, 2021, Vol. 8, No. 1 